\title{
Feasibility of using liquefied gas HFO-1234ze (trans-1,3,3,3-tetrafluoroprop-1-ene) as an alternative to conventional solvents for solid-liquid extraction of food ingredients and natural products
}

\author{
Vincent Rapinel ${ }^{\mathrm{a}, \mathrm{b}, \mathrm{c}}$, Cassandra Breil ${ }^{\mathrm{c}}$, Caroline Makerri ${ }^{\mathrm{c}}$, Magali Jacotet-Navarro ${ }^{\mathrm{c}}$, \\ Njara Rakotomanomana ${ }^{c}$, Alain Vallageas ${ }^{\mathrm{a}}$, Farid Chemat ${ }^{\mathrm{b}, \mathrm{c}, *}$ \\ a Celsius Sarl, 184 Chemin du Bouray, 38200 Villette de Vienne, France \\ ${ }^{\mathrm{b}}$ Plateforme d'Eco-Extraction de Valréas (PEEV), 14 D Route de Grillon, 84600 Valréas, France \\ ${ }^{\mathrm{c}}$ Université d'Avignon et des Pays de Vaucluse, INRA, UMR408, GREEN Extraction Team, 84000 Avignon, France
}

A R T I C L E I N F O

Keywords:

Extraction

Alternative solvent

Liquefied gas

Economic evaluation

Safety consideration

\begin{abstract}
A B S T R A C T
This study was designed to evaluate the applicability of a new liquefied gas, HFO-1234ze, as a safe alternative for the substitution of usual solvents such as $n$-hexane, acetone or ethanol, for the extraction of natural products. The performance of this new solvent was assessed using several plant materials: rapeseeds, carrots, olive leaves and rosemary leaves. An in-silico evaluation of the relative performance of each solvent was performed using Hansen solubility parameters and COSMO-RS model. Extraction experiments were also performed at laboratory scale on several plant materials, in order to determine qualitative and quantitative characteristics of the extracts. Finally, safety considerations, as well as energetic and environmental impacts using this new liquefied gas solvent were evaluated in a scale-up perspective.
\end{abstract}

\section{Introduction}

A solvent can be defined as "a liquid that has the property to dissolve, dilute or extract other materials without causing chemical modification of these substances or itself. The solvents are able to implement, apply, clean or separate products". Conventional organic solvents such as $n$-hexane, methanol, acetone or dichloromethane are usually used in solid-liquid extractions. As an example, the global market size, for $n$-hexane as solvent, was estimated at 1.75 billion dollars in 2015, and extraction consumes about 35\% of the global volume (Grand View Research, 2016). Petroleum solvents are very efficient to dissolve a wide range of natural ingredients and are easily eliminated by evaporation at the end of the process. Unfortunately most of these organic solvents are known to be highly flammable and also toxic for human and

* Corresponding author. Université d'Avignon et des Pays de Vaucluse, INRA UMR408, GREEN Extraction Team, 84000 Avignon, France.

E-mail address: farid.chemat@univ-avignon.fr (F. Chemat). environment (Henderson et al., 2011). Faced to the tightening of legislation, industrials are forced to find efficient, safer and greener solvents.

Solvent substitution process is a complex approach, which must consider various aspects. Ideally the "perfect" alternative solvent must have several advantages: no toxicity for human and environment, non-flammable, no emission of volatile organic compounds, low cost, bio-sourced even completely or partially, high solvation power, low viscosity, and easy to evaporate (Sicaire, 2016). However, replacing hazardous solvents by available green solvents does not always mean eliminating all the hazards and issues. In fact, in most of case the modification of a process is associated with new risks and hazards.

This search for alternative solvents has revived the interest for liquefied gases, i.e. gases used in liquid state, as extraction solvents (Liquefied Gas Extraction - LGE). Recently, many studies showed that several liquefied gases, such as n-butane (Capeletto et al., 2016; Liu, Wang, Li, Wang, \& Qin, 2015; Novello et al., 2015; Rapinel et al., 2016), n-propane (Ahangari \& Sargolzaei, 2012; Castaneda-Acosta, Cain, Fischer, \& Knopf, 1995; Corso et al., 2010), dimethyl ether 
Version définitive du manuscrit publiée dans / Final version of the manuscript published in :

LWT - Food Science and Technology (2017), Vol. 83, p. 225-234, DOI: 10.1016/j.Iwt.2017.05.027

Journal homepage : http://www.elsevier.com/locate/lwt

(Kanda, Kamo, Machmudah, Wahyudiono, \& Goto, 2014; Hideki; Kanda, Li, Ikehara, \& Yasumoto-Hirose, 2015; Sakuragi, Li, Aoki, Otaka, \& Makino, 2016), 1,1,1,2-tetrafluoroethane (Cerny, 2000; Han, Ma, Wang, \& Xue, 2012; Lapkin, Plucinski, \& Cutler, 2006), could be used as new alternative solvents for the extraction of natural products. For now, their use is still limited by their flammability (alkanes, ethers ...). Only 1,1,1,2-tetrafluoroethane is nonflammable but its use will be progressively phased out due to its impact on the greenhouse effect (Suberu, Yamin, Cornell, Sam, \& Lapkin, 2016).

As 1,1,1,2-tetrafluoroethane - also known as R134a - is widely used as refrigerant gas, refrigeration industrial intensively searched for a greener alternative. Their research resulted in two new fluorinated gases, named 2,3,3,3-tetrafluoropropene (HFO-1234yf) and 1,3,3,3-tetrafluoropropene (HFO-1234ze). HFOs (HydroFluoro-Olefins) are 4th generation refrigerants, non-toxic and non-flammable, without impact on the ozone layer (Ozone depletion potential $=0$ ) and only little greenhouse effect (Global warming potential $=4$ and 6 respectively) due to a short atmospheric lifetime (Achaichai, 2010). Eventually, studies on the degradation of HFOs (Luecken et al., 2010; Wallington, Sulbaek Andersen, \& Nielsen, 2010) showed that tetrafluoropropenes are likely to be degraded into HF and $\mathrm{CF}_{3} \mathrm{COOH}$. Fortunately, based on the current hydrofluorocarbons emissions, the authors calculated that the amounts of degradation products will not be sufficient to generate any environmental impacts, even for the most sensitive aquatic organisms.

HFOs were initially developed for refrigerant purpose, but their interesting properties make them suitable for LGE. In 2016, a promising research has been achieved by Suberu et al. (2016) on the extraction of artemisinin, an antimalarial substance, using HFO$1234 y f$ as alternative to R134a.

Based on their similar chemical structure, only few differences of solvation properties are expected between both HFOs. Moreover, HFO-1234ze currently costs around $15 € / \mathrm{kg}$ (price for 1 ton in 2016, Inventec Performance Chemicals, St Priest, France), i.e. five times cheaper than HFO-1234yf. For these reasons, we decided to choose HFO-1234ze as liquefied gas instead of HFO-1234yf.

In this paper, the feasibility of using liquefied HFO-1234ze as solvent for extracting compounds of different polarities will be compared to conventional solvents through two approaches: a theoretical approach with predictive computational tools, HSP (Hansen Solubility Parameters) and COSMO-RS (COnductor like Screening MOdel for Real Solvents), coupled with lab-scale experimentations. Four plant materials were chosen for the comparative study: rapeseeds (Brassica napus L.) for the extraction of fats and oils, carrots (Daucus carota L.) for the extraction of high-value products i.e. $\alpha$ and $\beta$-carotene, olive leaves (Olea europaea) for the extraction of polyphenols i.e. oleuropein and tyrosol, rosemary leaves (Rosmarinus officinalis L.) for the extraction of polyphenols and terpenes with antioxidant activity, such as rosmarinic acid and carnosic acid. The extracts have been analyzed quantitatively (extraction yield) and qualitatively (GC, HPLC and HPTLC) in order to compare the efficiency of HFO-1234ze regarding conventional solvents (hexane, ethanol, acetone) for the extraction of natural products (Fig. 1). Finally, the industrial application of this new liquefied gas solvent was evaluated in terms of safety, regulation and environmental impacts.

\section{Materials and methods}

\subsection{Chemicals}

For laboratory-scale extractions, $n$-hexane analytical grade, ethanol 95\% purity and acetone technical grade were purchased from VWR International (Radnor, USA). Trans-1,3,3,3Tetrafluoroprop-1-ene (HFO-1234ze) 99.5\% purity was purchased from Inventec Performance Chemical (St Priest, France).

For analytical procedures, all reagents were HPLC grades. Acetonitrile, ammonium acetate, dichloromethane, primuline and potassium chloride were purchased from Sigma-Aldrich (St. Louis, USA). $\beta$-carotene (>98\% UV purity) was purchased from Extrasynthèse (Genay, France). Oleuropein (HPLC grade, $\geq 98 \%$ ), carnosic acid (HPLC grade, $\geq 97 \%$ ), Fatty Acids Methyl Esters mix (Supelco 37 FAME mix), triheptadecanoin (C17:0 TAG, 99\% purity), pentadecanoic acid (C15:0, 99\% purity), 1-glyceryl palmitate (MAG), 1,3glyceryl palmitate (DAG), glyceryl tripalmitate (TAG), palmitic acid (FFA), ergosterol, phosphatidylcholine, phosphatidic acid, phosphatidylethanolamine and lysophosphatidylcholine were purchased from Sigma-Aldrich (St. Louis, USA). Chloroform, n-

Theoretical procedure

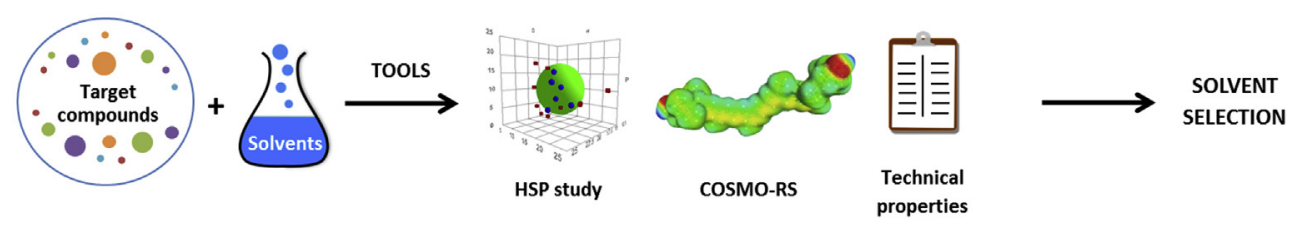

Experimental procedure
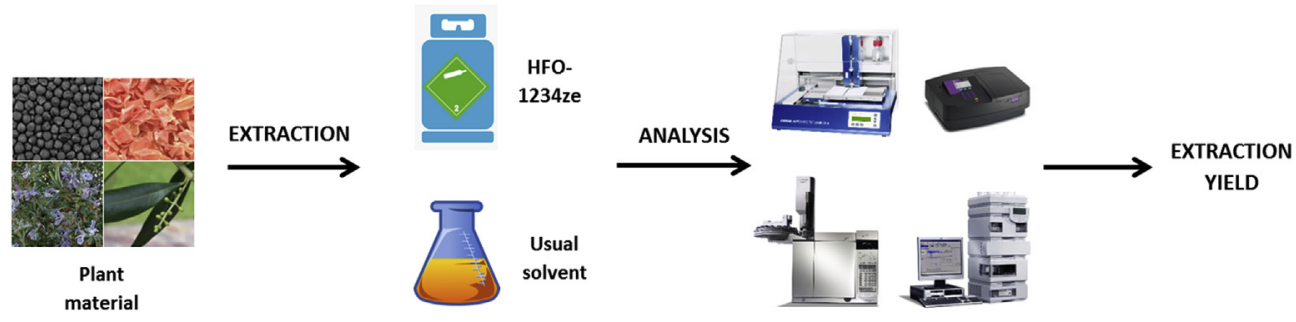

Fig. 1. Theoretical and experimental procedures. 
Version définitive du manuscrit publiée dans / Final version of the manuscript published in :

LWT - Food Science and Technology (2017), Vol. 83, p. 225-234, DOI: 10.1016/j.Iwt.2017.05.027

Journal homepage : http://www.elsevier.com/locate/lwt

hexane, acetone, diethyl ether, acetic acid, methyl acetate, isopropanol and methanol were sourced from VWR International (Darmstadt, Germany).

\subsection{Plant materials}

Dried carrots, rapeseeds, olive leaves and rosemary leaves were purchased from Herbier du Diois (Chatillon-en-Diois, France).

\subsection{Liquefied gases apparatus and extraction procedure}

Extractions were performed on a 1-liter pilot plant presented in Fig. 2 (NECTACEL ${ }^{\circledR}$, Celsius sarl, Villette de Vienne, France). The results of a previous work showed that extractions performed with NECTACEL ${ }^{\circledR}$ unit were limited by a slow mass transfer due to a lack of stirring (Rapinel et al., 2016). Hence a magnetic-drive stirrer was recently added in the extractor in order to ensure a proper solvent stirring (see Fig. 3).

\subsection{Reference extractions}

Reflux extraction in n-hexane, using $10 \mathrm{~g}$ of raw material and $100 \mathrm{~mL}$ of $n$-hexane, was used as reference procedure for rapeseed and carrots extraction (Sicaire, Vian, Fine, Joffre, et al., 2015; YaraVaron et al., 2016).

Maceration using a mixture ethanol/water was used as reference procedure for the extraction of olive leaves (Yateem, Afaneh, \& Al-Rimawi, 2014). $10 \mathrm{~g}$ of raw material are extracted with $100 \mathrm{~mL}$ of ethanol/water (80:20, mass ratio). The mixture was heated at $60^{\circ} \mathrm{C}$ for $1 \mathrm{~h}$.

Maceration under reflux using acetone was used as reference procedure for the extraction of rosemary leaves (European Food Safety Authority, 2008) for rosemary leaves, at boiling point temperature $\left(56^{\circ} \mathrm{C}\right)$ for $1 \mathrm{~h}$. Then $83.5 \mathrm{~g}$ of raw material were placed in a flask containing $500 \mathrm{~mL}$ of acetone.

\subsection{Extract analysis}

Identification of carotenoids in carrot oleoresin was performed by high performance liquid chromatography (Agilent 1100) equipped with a UV-Vis detector using a protocol described in a previous publication (Yara-Varon et al., 2016). The carotenoid content in the extracts was measured using UV/Vis Spectrophotometer (Biochrom Libra S22, Cambridge, England) according to the protocol explained by Yara-Varon et al. (2016).

The lipid classes of rapeseed oils were determined by HP-TLC using the protocol described by Breil, Meullemiestre, Vian, and Chemat (2016). The fatty acid composition of the rapeseed oils was determined using gas chromatography. As described by Sicaire, Vian, Fine, Carre, et al. (2015).

Polyphenols content in the extracts was measured spectrophotometrically (Biochrom Libra S22 UV/Vis Spectrophotometer, Cambridge, England) in a $1 \mathrm{~cm}$ optical path-length quartz cell at $760 \mathrm{~nm}$ for oleuropein. A calibration curve of oleuropein in ethanol was performed in concentration range $0.25-1.0 \mathrm{mg} / \mathrm{mL}$.

Determination of carnosic acid content in rosemary leaves extracts was done by HPLC (Agilent 1100, France) using the protocol described by Jacotet-Navarro et al. (2015).

\subsection{Computational method: Hansen solubility parameters and COSMO-RS calculations}

For Hansen Solubility Parameters (HSP) solvent optimization, the relative energy differences (REDs) of each couple solute/solvent were calculated using the software HSPiP Version 5.0.03 (HansenSolubility, Hørsholm, Denmark) using the method previously described by Yara-Varon et al. (2016).

The principle of COSMO-RS modeling of solvent-solute interactions has been explained in previous publications (Sicaire, Vian, Fine, Carre, et al., 2015; Yara-Varon et al., 2016).
(A)

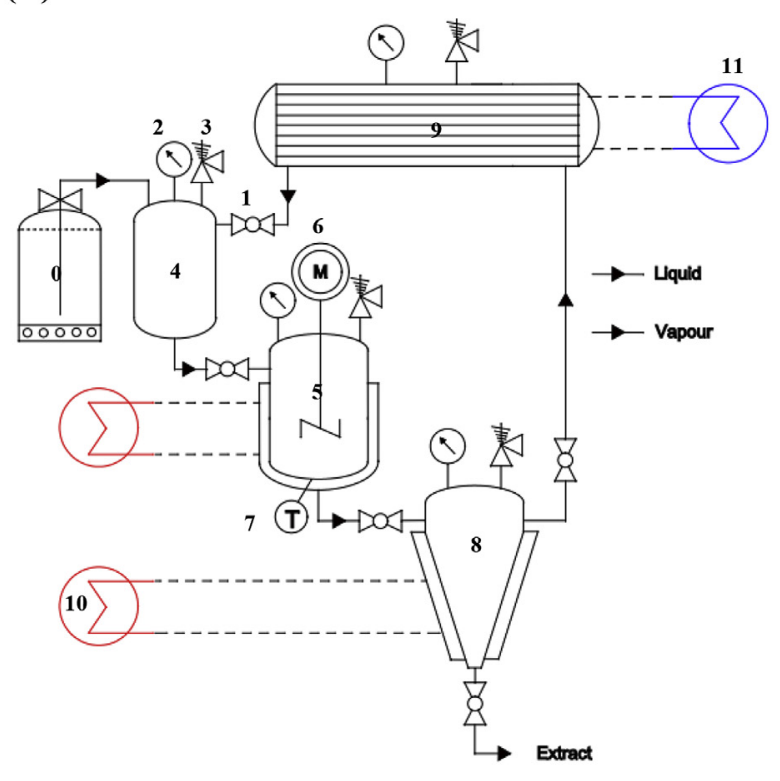

(B)

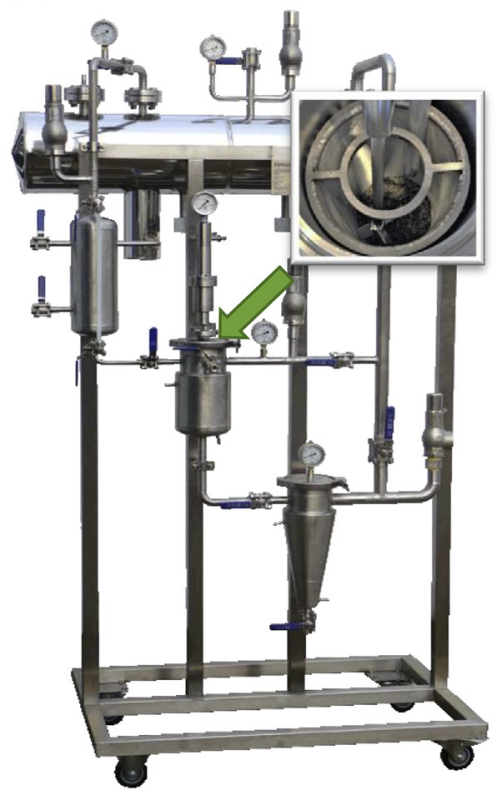

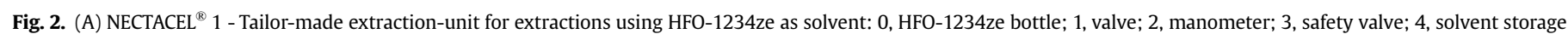

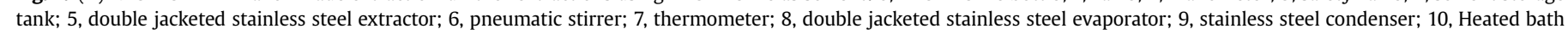
circulator; 11, Cooling bath circulator - (B) 1-liter extraction unit manufactured by Celsius Sarl (Villette de Vienne, France). 
Version définitive du manuscrit publiée dans / Final version of the manuscript published in :

LWT - Food Science and Technology (2017), Vol. 83, p. 225-234, DOI: 10.1016/j.Iwt.2017.05.027

Journal homepage : http://www.elsevier.com/locate/lwt

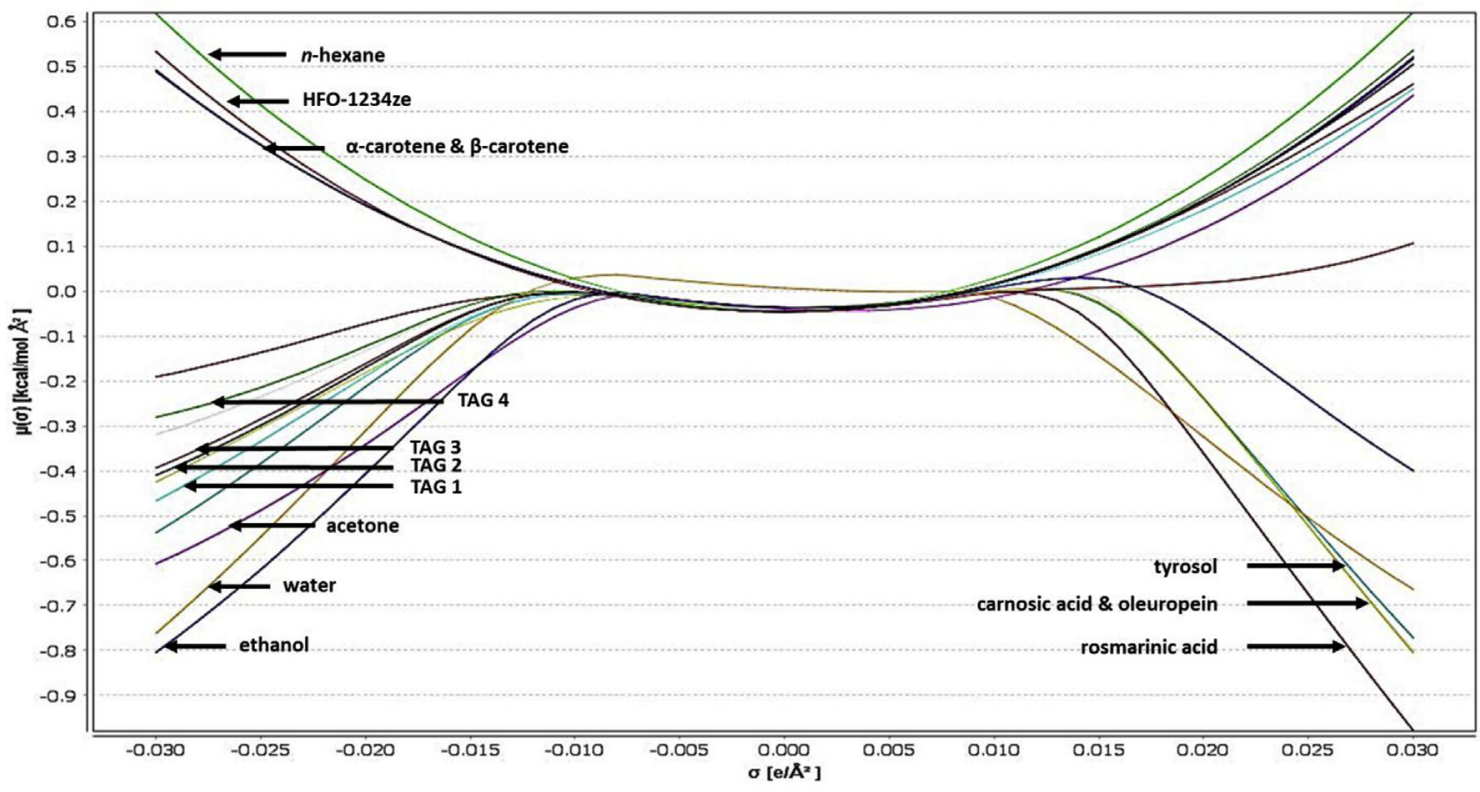

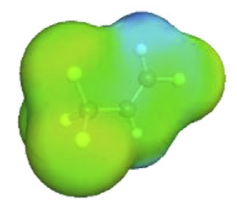

HFO-1234ze

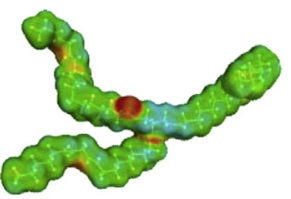

TAG1

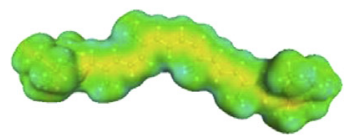

$\alpha$-carotene

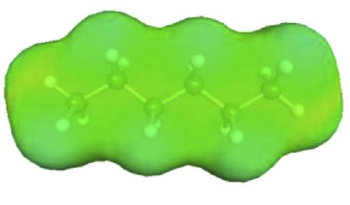

n-hexane

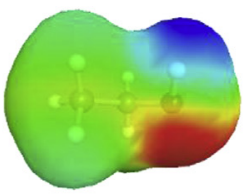

ethanol

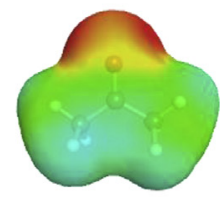

acetone

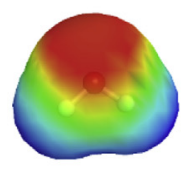

water

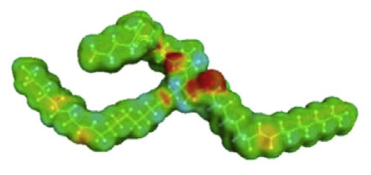

TAG2

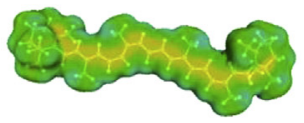

$\beta$-carotene

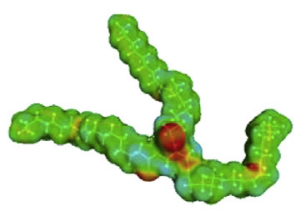

TAG3

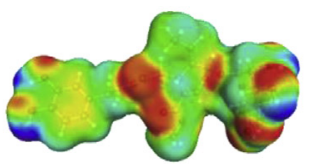

oleuropein

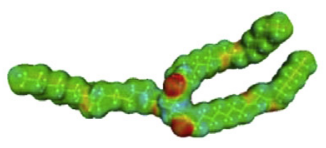

TAG4

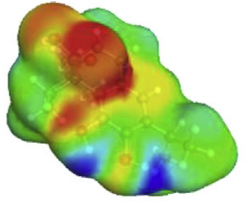

carnosic acid

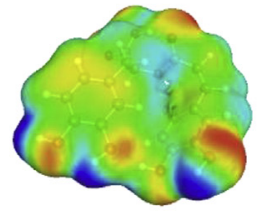

rosmarinic acid

Fig. 3. - $\sigma$-potentials and $\sigma$-surfaces of solutes and solvents calculated using COSMO-RS model.

\subsection{Physicochemical properties comparison}

In order to determine if HFO-1234ze can be an alternative to conventional solvent, technical properties of each solvent were compared.

Table 1 reports physicochemical properties of liquefied HFO- 1234ze, $n$-hexane, ethanol, acetone and water. Technical data was obtained from ACD-labs and from suppliers (Sigma-Aldrich, Inventec Performance Chemicals). The global energy of evaporation for $1 \mathrm{~kg}$ of liquid solvent was calculated using the equation (Eq. (1)), considering the following initial state: pure incompressible liquid at $25^{\circ} \mathrm{C}$ and $101 \mathrm{kPa}$ for usual solvents, $570 \mathrm{kPa}$ for HFO-1234ze. 
Table 1

Comparison of technical properties of extraction solvents.

\begin{tabular}{|c|c|c|c|c|c|c|}
\hline Properties & Unit & HFO-1234ze & n-hexane & Ethanol & Acetone & Water \\
\hline \multicolumn{7}{|l|}{ Chemical structure } \\
\hline Molecular formula & & $\mathrm{C}_{3} \mathrm{H}_{2} \mathrm{~F}_{4}$ & $\mathrm{C}_{6} \mathrm{H}_{14}$ & $\mathrm{C}_{2} \mathrm{H}_{6} \mathrm{O}$ & $\mathrm{C}_{3} \mathrm{H}_{6} \mathrm{O}$ & $\mathrm{H}_{2} \mathrm{O}$ \\
\hline Molecular weight & {$[\mathrm{g} / \mathrm{mol}]$} & 114.04 & 86.18 & 46.07 & 58.08 & 18.02 \\
\hline Density $\left(25{ }^{\circ} \mathrm{C}\right)$ & {$\left[\mathrm{kg} / \mathrm{m}^{3}\right]$} & 1163 & 650 & 789 & 785 & 998 \\
\hline Viscosity $\left(25^{\circ} \mathrm{C}\right)$ & [mPa.s] & 0.20 & 0.32 & 1.2 & 0.32 & 1.0 \\
\hline Boiling point (101.3 kPa) & {$\left[{ }^{\circ} \mathrm{C}\right]$} & -18.9 & 68.5 & 78.3 & 56.2 & 100 \\
\hline Specific heat $\left(25{ }^{\circ}\right)$ & {$\left[\mathrm{kJ} / \mathrm{kg} \cdot{ }^{\circ} \mathrm{C}\right]$} & 1.386 & 2.23 & 2.43 & 2.18 & 4.18 \\
\hline Latent heat of vaporization & {$[\mathrm{kJ} / \mathrm{kg}]$} & $162.9^{\mathrm{a}}$ & 334 & 843 & 500 & 2260 \\
\hline Energy to evaporate $1 \mathrm{~kg}$ from $25^{\circ} \mathrm{C}$ & [kW.h] & $0.05^{\mathrm{a}}$ & 0.12 & 0.27 & 0.16 & 0.71 \\
\hline $\log _{10} P$ & & 1.26 & 3.9 & -0.16 & -0.19 & n.a. \\
\hline Solubility in water $\left(25^{\circ} \mathrm{C}\right)$ & {$\left[\mathrm{kg} / \mathrm{m}^{3}\right]$} & 0.37 & 0.01 & miscible & miscible & n.a. \\
\hline Flash point & {$\left[{ }^{\circ} \mathrm{C}\right]$} & n.a. & -23 & 13 & -18 & n.a. \\
\hline ODP ${ }^{b}$ & eq. CFC-11 & 0 & n.a. & n.a. & n.a. & n.a. \\
\hline $\begin{array}{l}\text { GWP }_{100}{ }^{\mathrm{c}} \\
\text { Hansen Solubility Parameters }\end{array}$ & eq. $\mathrm{CO}_{2}$ & 6 & n.a. & n.a. & n.a. & n.a. \\
\hline$\delta_{\mathrm{d}}$ & {$\left[\mathrm{MPa}^{1 / 2}\right]$} & 13.9 & 14.9 & 15.8 & 15.4 & 15.5 \\
\hline$\delta_{\mathrm{p}}$ & & 3.3 & 0 & 8.8 & 10.4 & 16.0 \\
\hline$\delta_{\mathrm{h}}$ & & 2.8 & 0 & 19.4 & 7.0 & 42.3 \\
\hline
\end{tabular}

a Value at $30^{\circ} \mathrm{C}$ and $570 \mathrm{kPa}$

b Ozone Depletion Potential.

c Global Warming Potential (100 years); n.a. = not applicable.

$E_{\text {tot }}=E_{\text {heat }}\left(T_{0} \rightarrow T_{b}\right)+E_{v a p}=\int_{T_{0}}^{T_{b}} C p_{m} \cdot d T+\Delta H_{v a p}\left(T_{b}\right)$

Where $E_{\text {tot }}(\mathrm{kJ} / \mathrm{kg})$ is the energy required to evaporate $1 \mathrm{~kg}$ of solvent starting from $\mathrm{T}_{0}=25^{\circ} \mathrm{C}, \mathrm{E}_{\text {heat }}(\mathrm{kJ} / \mathrm{kg})$ is the energy required to heat up the solvent of $1{ }^{\circ} \mathrm{C}, \mathrm{E}_{\mathrm{vap}}(\mathrm{kJ} / \mathrm{kg})$ is the energy required to vaporize $1 \mathrm{~kg}$ of liquid, $\mathrm{Cp}_{\mathrm{m}}(\mathrm{kJ} / \mathrm{kg} . \mathrm{K})$ is the specific heat, $\mathrm{T}_{\mathrm{b}}\left({ }^{\circ} \mathrm{C}\right)$ is the boiling point of the solvent in the process conditions of pressure and $\Delta \mathrm{H}_{\mathrm{vap}}(\mathrm{kJ} / \mathrm{kg})$ is the vaporization enthalpy at the boiling point.

\section{Results and discussion}

3.1. HFO-1234ze as alternative solvent to usual solvents: properties comparison

As shown in Table 1, liquefied HFO-1234ze has very particular properties compared to usual organics solvents such as $n$-hexane, ethanol and acetone. As most halogenated solvents, HFO-1234ze has a higher density $\left(1163 \mathrm{~kg} / \mathrm{m}^{3}\right)$ compared to $n$-hexane or acetone (650 and $785 \mathrm{~kg} / \mathrm{m}^{3}$ respectively). As most liquefied gases, HFO-1234ze also has a very low viscosity ( $0.20 \mathrm{mPa}$ ), lower than acetone and $n$-hexane $(0.32 \mathrm{mPa} s)$ and even six times lower than ethanol (1.2 $\mathrm{mPa} \mathrm{s})$. Its low viscosity facilitates the flow of solvent inside particles of plant material and thus enhances the internal mass transfer (Hasan \& Farouk, 2013). Hansen solubility parameters and $\log _{10} \mathrm{P}$ values show that HFO-1234ze can be defined as slightly apolar $\left(\log _{10} \mathrm{P}=1.26\right)$, compared with lipophilic solvents such as $n$-hexane $\left(\log _{10} \mathrm{P}=3.9\right)$ or with more hydrophilic solvents such as acetone $\left(\log _{10} \mathrm{P}=-0.19\right)$ or ethanol $\left(\log _{10} \mathrm{P}=-0.16\right)$. HFO$1234 z e$ is not fully miscible with water but its partial solubility is higher than $n$-hexane with 0.37 and $0.01 \mathrm{~kg} / \mathrm{m}^{3}$ respectively, at $25^{\circ} \mathrm{C}$. The most significant difference between HFO-1234ze and the other solvents is the amount of energy required to evaporate $1 \mathrm{~kg}$ of solvent from $25^{\circ} \mathrm{C}$ : $0.05 \mathrm{~kW}$ h for HFO-1234ze, 0.12 for $n$-hexane, 0.27 for ethanol, 0.16 for acetone and 0.71 for water. This lower energy consumption is a consequence of a low specific heat $(0.2 \mathrm{~kJ} /$ kg.K at $25^{\circ} \mathrm{C}$ ) and latent heat of vaporization $\left(162.9 \mathrm{~kJ} / \mathrm{kg}\right.$ at $30^{\circ} \mathrm{C}$ and $570 \mathrm{kPa}$ ), due to lower Van Der Walls interactions. The choice of the evaporation process also has an impact on the energy consumption: when HFO-1234ze is evaporated under pressure, the solvent is closer to its critical point and the value of $\Delta \mathrm{H}_{\mathrm{vap}}$ is lower than at atmospheric pressure (195 kJ/kg at $101 \mathrm{kPa})$. In the end the energy saving with HFO-1234ze using an isobaric process is about $60 \%$ compared to $n$-hexane, $80 \%$ compared to ethanol and $95 \%$ compared to water.

\subsection{Evaluation of target compounds solubility in HFO-1234ze vs.} usual solvents using Hansen Solubility Parameters and COSMO-RS

Hansen solubility parameters (HSP) and COSMO-RS model were used as prediction tools for the evaluation of the ability of solvents to dissolve major components of several plant materials. In this paper, 4 representative triacylglycerols (TAG1 [R1: C18:3n-3, R2: C18:2n-6, R3: C18:2n-6]; TAG2 [R1: C18:1n-9, R2: C18:1n-9, R3: C18:2n-6]; TAG3 [R1: C18:1n-9, R2: C18:1n-9, R3: C18:1n-9]; TAG4 [R1: C18:1n-9, R2: C18:2n-6, R3: C18:2n-6]); 2 carotenoids ( $\alpha-$ carotene and $\beta$-carotene); 2 polyphenols (oleuropein and tyrosol) and 2 organic acids (carnosic acid and rosmarinic acid) were defined as target component of rapeseeds, carrots, olive leaves and rosemary leaves, respectively. Several solvents were selected for the simulations: HFO-1234ze as liquefied gas and usual solvents such as $n$-hexane, ethanol, acetone and water.

For Hansen parameters, the solubilization power of a solvent toward a solute is evaluated by the relative energy difference (RED) calculated by the software. Table 2 shows the RED values for the selected solvents with TAGs, carotenoids, polyphenols and organic acids. COSMO-RS simulation was also performed to determine the relative solubility of the target components in several solvents. Table 3 reports the solubility results, expressed in $\log _{10}\left(\mathrm{x}_{\text {solub }}\right)$. The results of COSMO-RS simulations are mostly in accordance with the HSP evaluation. Considering TAGs, $n$-hexane and HFO-1234ze showed the best relative solubility values i.e. $\log _{10}\left(\mathrm{x}_{\text {solub }}\right)=0$. For carotenes, $n$-hexane is still the best solvent whereas HFO-1234ze showed slightly lower relative solubility power $\left(\log _{10}\left(\mathrm{x}_{\text {solub }}\right)=-0.32\right)$. COSMO-RS evaluated that HFO-1234ze is worse than reference solvents for the solubilization of oleuropein $\left(\log _{10}\left(\mathrm{x}_{\text {solub }}\right)=-2.15\right)$, tyrosol $\left(\log _{10}\left(\mathrm{x}_{\text {solub }}\right)=-1.31\right)$, rosmarinic $\operatorname{acid}\left(\log _{10}\left(\mathrm{x}_{\text {solub }}\right)=-1.11\right)$ and carnosic acid $\left(\log _{10}\left(\mathrm{x}_{\text {solub }}\right)=-0.63\right)$. 
Version définitive du manuscrit publiée dans / Final version of the manuscript published in :

LWT - Food Science and Technology (2017), Vol. 83, p. 225-234, DOI: 10.1016/j.Iwt.2017.05.027

Journal homepage : http://www.elsevier.com/locate/lwt

Table 2

The relative energy difference (RED) values for HSP.

\begin{tabular}{ccccccccc}
\hline Compounds & $\boldsymbol{\delta}_{\mathbf{D}}$ & $\boldsymbol{\delta}_{\mathbf{P}}$ & $\boldsymbol{\delta}_{\mathbf{H}}$ & $\begin{array}{c}\text { HFO- } \\
\mathbf{1 2 3 4 z e}\end{array}$ & $\boldsymbol{n}$-hexane & Ethanol & Acetone & Water \\
\hline TAG 1 $^{\mathrm{a}}$ & 16.4 & 1.8 & 3.0 & 2.61 & 2.31 & 8.94 & 4.83 & 20.91 \\
TAG 2 $^{\mathrm{a}}$ & 16.6 & 1.7 & 2.5 & 2.82 & 2.27 & 9.20 & 5.02 & 21.17 \\
TAG 3 $^{\mathrm{a}}$ & 16.6 & 1.6 & 2.3 & 2.84 & 2.20 & 9.31 & 5.11 & 21.28 \\
TAG 4 $^{\mathrm{a}}$ & 16.5 & 1.7 & 2.7 & 2.72 & 2.26 & 9.10 & 4.95 & 21.08 \\
\hline -carotene & 17.4 & 0.0 & 1.5 & 3.92 & 2.61 & 10.10 & 6.18 & 21.99 \\
$\boldsymbol{\beta}_{\text {-carotene }}$ & 17.4 & 0.8 & 1.7 & 3.76 & 2.67 & 9.84 & 5.80 & 21.76 \\
\hline Oleuropein & 17.2 & 13.1 & 19.9 & 10.39 & 12.13 & $2.92^{\mathrm{b}}$ & 6.81 & 11.42 \\
Tyrosol & 19.0 & 8.1 & 17.1 & 9.10 & 10.31 & $4.89^{\mathrm{b}}$ & 6.25 & 13.66 \\
\hline Carnosic acid & 18.5 & 4.2 & 9.2 & 5.62 & 6.21 & 6.21 & 4.45 & 17.82 \\
\hline Rosmarinic acid & 19.9 & 9.3 & 16.9 & 9.73 & 10.86 & 4.29 & 6.65 & $10.01^{\mathrm{c}}$ \\
\hline
\end{tabular}

Grey $=$ Reference solvent; Green $=$ equivalent or better than reference $\left(\mathrm{RED}<\mathrm{RED}_{\text {ref }}+1\right)$; Yellow $=$ Equivalent or slightly worse than reference $\left(\operatorname{RED}_{\text {ref }}+1<\mathrm{RED}<\mathrm{RED}_{\text {ref }}+3\right)$; Red = worse than reference $\left(\operatorname{RED}>\mathrm{RED}_{\text {ref }}+3\right)$

${ }^{\mathbf{a}}$ TAG $=$ TriAcylGlycerol. TAG 1 (R1: C18:3n-3, R2: C18:2n-6, R3: C18:2n-6), TAG 2 (R1: C18:2n-6, R2: C18:1n-9, R3: 18:1n-9), TAG 3 (R1: C18:1n-9, R2: C18:1n-9, R3: C18:1n-9), TAG 4 (R1: C18:1n $-9, \mathrm{R} 2: \mathrm{C} 18: 2 n-6, \mathrm{R} 3: \mathrm{C} 18: 2 n-6)$

${ }^{\text {b }}$ solvent $=$ ethanol $/$ water $(80: 20$, mass ratio $)$

${ }_{\text {solvent }}=$ ethanol $/$ water $(30: 70$, mass ratio $)$

Table 3

COMSO-RS relative solubility values, $\log _{10}\left(\mathrm{x}_{\text {solub }}\right)$ at $40^{\circ} \mathrm{C}$.

\begin{tabular}{cccccc}
\hline Compounds & HFO-1234ze & $\boldsymbol{n}$-hexane & Ethanol & Acetone & Water \\
\hline TAG 1 $^{\mathrm{a}}$ & 0.00 & -0.48 & -1.72 & 0.00 & -22.02 \\
TAG 2 $^{\mathrm{a}}$ & 0.00 & 0.00 & -2.30 & 0.00 & -24.35 \\
TAG 3 $^{\mathrm{a}}$ & 0.00 & 0.00 & -2.29 & 0.00 & -24.34 \\
TAG 4 $^{\mathrm{a}}$ & 0.00 & 0.00 & -2.56 & -0.07 & -25.06 \\
\hline -carotene $_{\beta \text {-carotene }}$ & -0.32 & 0.00 & -1.89 & 0.00 & -16.16 \\
\hline Oleuropein & -0.32 & -0.01 & -1.89 & 0.00 & -16.20 \\
Tyrosol & -2.15 & -6.49 & $0.00^{\mathrm{b}}$ & 0.00 & -4.13 \\
\hline Carnosic acid & -1.32 & -2.83 & $0.00^{\mathrm{b}}$ & 0.00 & -2.02 \\
Rosmarinic acid & -0.63 & -2.14 & 0.00 & 0.00 & -4.59 \\
\hline
\end{tabular}

Grey $=$ Reference solvent; Green $=$ equivalent or better than reference $\left(\log _{10}\left(\mathrm{x}_{\text {solub }}\right)=0\right)$; Yellow $=$ Equivalent or slightly worse than reference $\left(\log _{10}\left(\mathrm{x}_{\text {solub }}\right)>-1\right)$; Red $=$ worse than reference $\left(\log _{10}\left(\mathrm{x}_{\text {solub }}\right)<-1\right)$

${ }^{\mathbf{a}} \mathrm{TAG}=$ TriAcylGlycerol. TAG 1 (R1: C18:3n-3, R2: C18:2n-6, R3: C18:2n-6), TAG 2 (R1: C18:2n-6, R2: C18:1n-9, R3: 18:1n-9), TAG 3 (R1: C18:1n-9, R2: C18:1n-9, R3: C18:1n-9), TAG 4 (R1: C18:1n $-9, \mathrm{R} 2: \mathrm{C} 18: 2 n-6, \mathrm{R} 3: \mathrm{C} 18: 2 n-6)$

${ }^{\text {b }}$ solvent $=$ ethanol $/$ water $(80: 20$, mass ratio $)$

c solvent $=$ ethanol $/$ water $(30: 70$, mass ratio $)$

It can be concluded that both HSP and COSMO-RS simulations suggest that HFO-1234ze is a good potential candidate for the substitution of $n$-hexane for the extraction of lipophilic compounds, but is unlikely to substitute more polar or protic solvents such as ethanol/water or acetone for extraction of polyphenol or organic acids.
3.3. Qualitative and quantitative comparison of extracts from rapeseeds

Quantitative study of rapeseed oil extraction using $n$-hexane and HFO-1234ze are presented in Fig. 4. The extraction kinetics (Fig. 4-A) showed that for HFO-1234ze at $30{ }^{\circ} \mathrm{C}$, the extraction 

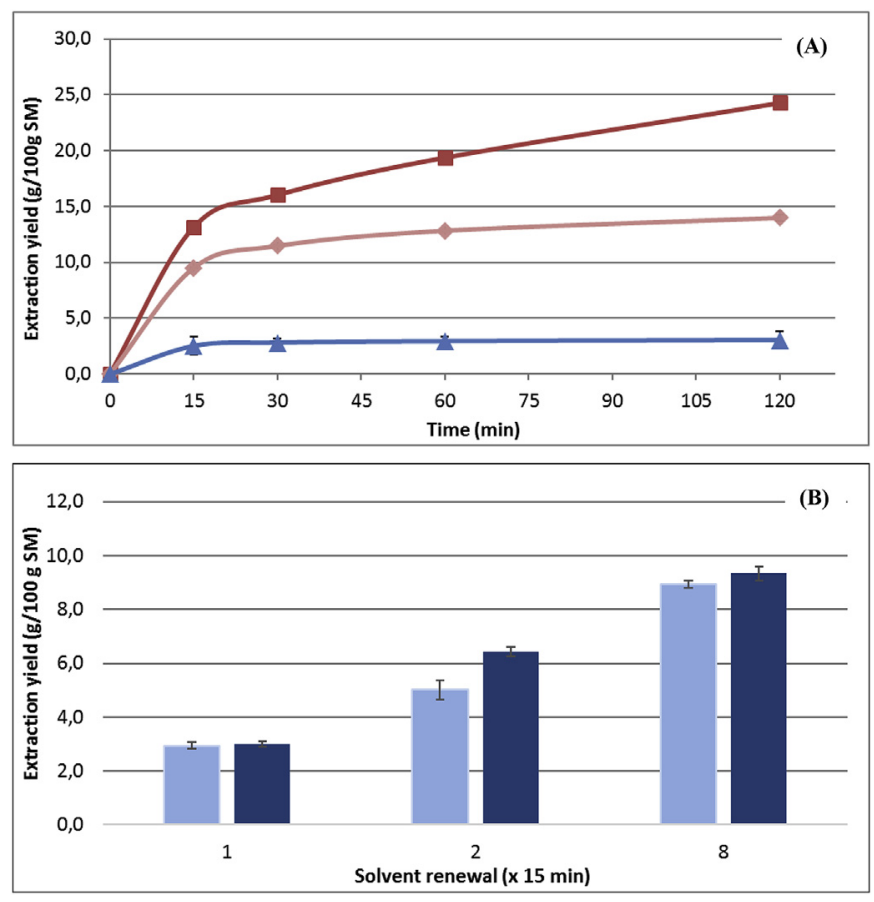

Fig. 4. (A) Extraction kinetics of rapeseed oil extracted with HFO-1234ze at $30{ }^{\circ} \mathrm{C}$ (triangles) and $n$-hexane at $30^{\circ} \mathrm{C}$ (diamonds) and $68^{\circ} \mathrm{C}$ (squares) - (B) Effect of HFO$1234 z e$ renewals on the extraction yield at $20^{\circ} \mathrm{C}$ (light blue) and $30^{\circ} \mathrm{C}$ (dark blue).

plateau is reached in only $15 \mathrm{~min}$, with a yield of $2.5 \%$. In comparison, $n$-hexane allowed extraction yields of $9.5 \%$ at $30{ }^{\circ} \mathrm{C}$ and $13.1 \%$ and $68{ }^{\circ} \mathrm{C}$ in only $15 \mathrm{~min}$. After $120 \mathrm{~min}$ of extraction, extraction yield with HFO-1234ze was only $3.0 \%$ at $30^{\circ} \mathrm{C}$, whereas extractions performed with $n$-hexane resulted in higher yields $\left(14 \%\right.$ at $30{ }^{\circ} \mathrm{C}$ and $25 \%$ at $68{ }^{\circ} \mathrm{C}$ ) as observed by Sicaire, Vian, Fine, Carre, et al, (2015). This difference is likely to be caused by a much higher solubility of rapeseed oil in $n$-hexane compared with HFO-1234ze.

Considering that the extraction plateau is reached rapidly with HFO-1234ze, a new set of experiments was made with successive solvent renewals every $15 \mathrm{~min}$, in order to improve the extraction yield. The easy vaporization of HFO-1234ze and the significant difference of boiling point with rapeseed oil compounds allowed complete solvent recycling ( $>95 \% \mathrm{vol}$ ) in only $10 \mathrm{~min}$. Results of extractions performed with a solvent/matrix contacting time of $2 \times 15$ and $8 \times 15 \mathrm{~min}$ are shown in Fig. 4-B.

Compared with the reference $(1 \times 15 \mathrm{~min})$, the solvent renewal substantially improved the extraction yield. At $30{ }^{\circ} \mathrm{C}$, HFO-1234ze enabled to reach an average oil yield of $6.4 \%$ and $9.5 \%$ with respectively 1 and 7 successive solvent renewals. These results are in accordance with the hypothesis of a rapid saturation of rapeseed oil in the solvent. The non-linear evolution of the extraction yield with the number of renewall suggests the exhaustion of the raw material after 7 renewals. However, there is still a gap between the final extraction yields obtained with HFO-1234ze (9.5\%) and $n$ hexane $(14 \%)$ at $30{ }^{\circ} \mathrm{C}$. Even if the difference of rapeseed oil solubility in both solvent may be a reason, the differences related to the apparatus used for extractions using $n$-hexane and HFO-1234ze (slower heat and mass transfer, losses in the equipment etc.) are also likely to impact the extract recovery.

At the same time, rapeseed oils obtained with HFO-1234ze and $n$-hexane were compared qualitatively with HP-TLC and GC to determine the lipid classes and the fatty acid distribution. HP-TLC analysis of the extracts showed that the only lipid class was triglycerides, with both solvents. Fatty acid distributions of the extracts obtained with HFO-1234ze and $n$-hexane are compared in Table 4.

Rapeseed oils from both solvents are composed of respectively: 28.82 and $29.49 \mathrm{~g} / 100 \mathrm{~g}$ of poly-unsaturated fatty acids, 64.86 and $64.27 \mathrm{~g} / 100 \mathrm{~g}$ of mono-unsaturated fatty acids and 6.31 and $6.24 \mathrm{~g} /$ $100 \mathrm{~g}$ of saturated fatty acids. Fatty acids distributions are similar for both studied solvents. Despite the difference of temperature ( $30{ }^{\circ} \mathrm{C}$ for HFO-1234ze; $68{ }^{\circ} \mathrm{C}$ for $n$-hexane) there was no marked impact on the fatty acid distribution, as observed in a previous work (Rapinel et al., 2016). Thus, rapeseed oils can be extracted by HFO-1234ze with an equal fatty acid composition compared to $n$ hexane, even at low temperatures $\left(30^{\circ} \mathrm{C}\right)$.

\subsection{Qualitative and quantitative comparison of extracts from dried carrots}

Quantitative and qualitative analysis of carotenoids extracts obtained with HFO-1234ze and $n$-hexane are presented in Table 5. Comparison of the extraction yields obtained with both solvents shows a lower extraction yield with HFO-1234ze, with $1.1 \mathrm{~g}$ of extract for $100 \mathrm{~g}$ of starting material against $4.3 \mathrm{~g} / 100 \mathrm{~g}$ with $n$ hexane. Moreover, the determination of the carotenoids contents in each extract by UV-Vis spectroscopy reveals that extract obtained with HFO-1234ze are about 6 times poorer in carotenes compared to $n$-hexane (4.75 vs $26.90 \mathrm{mg}$ of equivalent $\beta$-carotene for $100 \mathrm{~g}$ of starting material).

The HPLC analysis of the extract showed some differences in the distribution of $\beta$-carotene isomers. Indeed, 3 main isomers of $\beta$ carotene can be found in vegetable extracts: all-trans- $\beta$-carotene, 9 cis- $\beta$-carotene and 13 -cis- $\beta$-carotene. All-trans- $\beta$-carotene is the most abondant isomer with the higher antioxidant activity, but during extractions, undesirable $\beta$-carotene cis-isomers may be formed by thermal isomerization, resulting in a decrease of the antioxidant activity (Knockaert et al., 2013). Results presented in Table 5 show that extracts obtained with HFO-1234ze contain less cis isomers $(10.6 \%)$ than with $n$-hexane $(18.9 \%)$. The advanced degradation of all-trans- $\beta$-carotene into cis- $\beta$-carotene in extracts obtained with $n$-hexane is probably due to the higher extraction temperature.

These results suggest that liquefied HFO-1234ze only extracts of a little fraction of the carotenes content but the low temperature process leads to an extract of better quality.

\subsection{Qualitative and quantitative comparison of extracts from olive leaves}

Results of extractions of olive leaves with HFO-1234ze and ethanol/water (reference solvent) are reported in Table 6. The highest extraction yield was reached with the mixture ethanol/ water (18.3\%) whereas HFO-1234ze only achieve a yield of $0.2 \%$. Moreover, the results of the determination of the total polyphenols content show that extracts obtained with HFO-1234ze only $7 \%$ of polyphenols (considering that ethanol/water extraction reached $100 \%)$.

Even if the difference of extraction temperature between HFO1234ze $\left(30^{\circ} \mathrm{C}\right)$ and ethanol/water $\left(60^{\circ} \mathrm{C}\right)$ could explain the lower extraction yield, the low polyphenols content in the extracts demonstrates a low solubility in the solvent, in accordance with HSP and COSMO-RS predictions.

\subsection{Qualitative and quantitative comparison of extracts from rosemary leaves}

Rosemary leaves extracts obtained with HFO-1234ze and acetone (reference solvent) are compared both qualitatively and 
Version définitive du manuscrit publiée dans / Final version of the manuscript published in :

LWT - Food Science and Technology (2017), Vol. 83, p. 225-234, DOI: 10.1016/j.Iwt.2017.05.027

Journal homepage : http://www.elsevier.com/locate/lwt

Table 4

Fatty acid composition of rapeseed oil extracted with HFO-1234ze and $n$-hexane.

\begin{tabular}{lcc}
\hline \multirow{2}{*}{ Fatty acids } & HFO-1234ze & $n$-hexane \\
\cline { 2 - 3 } & $\mathrm{T}=30{ }^{\circ} \mathrm{C}$ & $\mathrm{T}=68^{\circ} \mathrm{C}$ \\
\hline unit $: g / 100 \mathrm{~g}$ & & \\
& & \\
$\mathrm{C} 16$ & $4.51 \pm 0.04$ & $4.54 \pm 0.06$ \\
$\mathrm{C} 18$ & $1.21 \pm 0.06$ & $1.08 \pm 0.19$ \\
$\mathrm{C} 18: 1 \mathrm{n}-9$ & $63.61 \pm 0.87$ & $63.02 \pm 0.20$ \\
$\mathrm{C} 18: 2 \mathrm{n}-6$ & $20.75 \pm 0.31$ & $20.16 \pm 0.07$ \\
$\mathrm{C} 18: 3 \mathrm{n}-3$ & $8.07 \pm 1.29$ & $9.33 \pm 0.01$ \\
$\mathrm{C} 20$ & $0.59 \pm 0.01$ & $0.62 \pm 0.05$ \\
$\mathrm{C} 20: 1$ & $1.25 \pm 0.01$ & $1.25 \pm 0.06$ \\
& & \\
$\Sigma$ SFAs & 6.31 & 6.24 \\
$\Sigma$ MUFAs & 64.86 & 64.27 \\
$\Sigma$ PUFAs & 28.82 & 29.49 \\
\hline
\end{tabular}

Table 5

Extraction yield and composition of carrot oleoresin obtained with HFO-1234ze and $n$-hexane.

\begin{tabular}{|c|c|c|c|c|c|c|c|}
\hline \multirow[t]{2}{*}{ Solvent } & \multirow[t]{2}{*}{$\mathrm{T}\left({ }^{\circ} \mathrm{C}\right)$} & \multirow[t]{2}{*}{ Time (h) } & \multirow[t]{2}{*}{ Extraction yield (g/100 g SM) } & \multirow[t]{2}{*}{ Carotenoid yield (mg/100 g SM) } & \multicolumn{3}{|c|}{ HPLC identified $\beta$-carotenes (g/100 g) } \\
\hline & & & & & 13 -cis- $\beta$-carotene & 9-cis- $\beta$-carotene & all trans- $\beta$-carotene \\
\hline HFO-1234ze & 30 & $3 \times 1 \mathrm{~h}$ & 1.16 & 4.75 & 7.2 & 3.4 & 89.4 \\
\hline$n$-hexane & 68 & $3 \times 1 \mathrm{~h}$ & 4.29 & 26.90 & 14.0 & 4.9 & 81.1 \\
\hline
\end{tabular}

SM, starting material.

Table 6

Extraction yield and composition of olive leaves extracts obtained with HFO-1234ze and a mixture ethanol/water.

\begin{tabular}{|c|c|c|c|c|}
\hline Solvent & $\mathrm{T}\left({ }^{\circ} \mathrm{C}\right)$ & Time $(\mathrm{h})$ & Extraction yield (g/100 g SM) & Relative polyphenols content (\%) \\
\hline HFO-1234ze & 30 & $3 \times 1 \mathrm{~h}$ & 0.2 & 7 \\
\hline Ethanol/water ( $80: 20$, mass ratio) & 60 & $3 \times 1 \mathrm{~h}$ & 18.3 & 100 \\
\hline
\end{tabular}

SM, starting material.

Table 7

Extraction yield and composition of rosemary leaves extracts obtained with HFO-1234ze and acetone.

\begin{tabular}{|c|c|c|c|c|}
\hline Solvent & $\mathrm{T}\left({ }^{\circ} \mathrm{C}\right)$ & Time $(\mathrm{h})$ & Extraction yield (g/100 g SM) & Carnosic acid content (g/100 g extract) \\
\hline HFO-1234ze & 30 & $3 \times 1 h$ & 2.1 & 2.45 \\
\hline acetone & 56 & $1 \mathrm{~h}$ & 11.8 & 14.45 \\
\hline
\end{tabular}

SM, starting material.

quantitatively. Results are reported in Table 7. The highest extraction yield was reached with acetone was (11.8\%) whereas HFO1234 ze only achieve a yield of $2.1 \%$. Results of HPLC analysis of the extracts exhibit a low content in carnosic acid in extracts obtained HFO-1234ze ( $2.44 \mathrm{~g} / 100 \mathrm{~g}$ of extract) whereas extracts with acetone show higher purity (14.5 g/100 g of extract), in accordance with the results obtained by the European Food Safety Authority (2008).

Once again, even if the difference of extraction yield is probably caused by a difference of extraction temperature between HFO1234ze $\left(30^{\circ} \mathrm{C}\right)$ and acetone $\left(56{ }^{\circ} \mathrm{C}\right)$, the low carnosic acid content in the extracts shows a low solubility in the solvent, in accordance with HSP and COSMO-RS predictions.

In conclusion, the experimental study tends to prove that the use of HFO-1234ze is not suitable for extraction of more polar compound such as polyphenols or organic acids, but could be used for lipophilic compounds. In particular, extractions of rapeseed oil were achieved even at low temperatures $\left(30^{\circ} \mathrm{C}\right)$ for HFO-1234ze with an equal oil composition compared to $n$-hexane. However, higher mass extraction yields were systematically obtained with the reference solvents ( $n$-hexane, ethanol/water, acetone). For oil extraction, this gap could be reduced by acting on temperature or by changing the process, leaving the batch process for a semicontinuous one (Lapkin et al., 2006).

Lastly, it has been shown that experimental data, HSP and COSMO-RS simulations were well correlated for almost each target compounds.

\section{Safety considerations}

The main hazards for workers are mainly generated by the solvent itself. As a big amount of liquefied gas is stored in the tanks 
Version définitive du manuscrit publiée dans / Final version of the manuscript published in :

LWT - Food Science and Technology (2017), Vol. 83, p. 225-234, DOI: 10.1016/j.Iwt.2017.05.027

Journal homepage : http://www.elsevier.com/locate/lwt
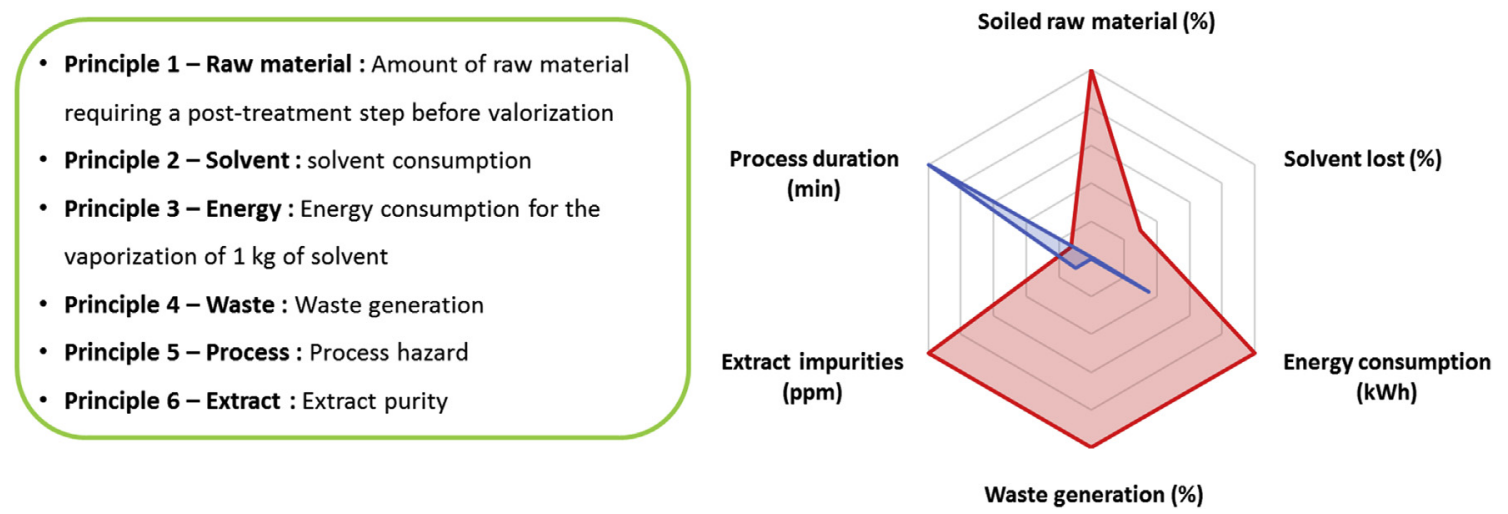

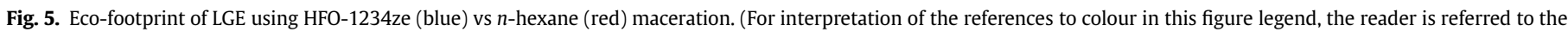
web version of this article.)

during the process, a leakage could generate a large volume of gaseous HFO-1234ze in the work atmosphere, leading to asphyxiation: $1 \mathrm{~m}^{3}$ of liquefied HFO-1234ze can generate about $200 \mathrm{~m}^{3}$ of gas.

\section{Eco-footprint: HFO-1234ze vs $n$-hexane for extraction of rapeseed oil}

Comparison of the environmental impact of HFO-1234ze versus $n$-hexane was assessed by determining an "eco-footprint", based on the 6 principles of green extraction defined by Chemat, Rombaut, Fabiano-Tixier, Pierson, and Bily (2015). The following 6 parameters were chosen as a basis to compare both extraction processes:

- Plant material: amount of plant material requiring a posttreatment step (\%)

- Solvent: direct solvent lost (\%)

- Energy: energy consumption for the evaporation of $1 \mathrm{~kg}$ of solvent (kW.h/kg)

- Co-products: amount of waste generated by the extraction ( $\mathrm{kg} /$ kg starting material)

- Process: process duration (min)

- Extract: amount contaminants in the extract (ppm)

A graphical representation of the eco-footprint is shown in Fig. 5. Using HFO-1234ze as extraction allows a lower environmental impact due to a lower energy consumption and a better extract quality without traces of hazardous solvent. Compared with $n$-hexane, HFO-1234ze generates no waste, and leave the defatted material safe for direct valorization as livestock feed. However, the limited solubility of rapeseed oil in HFO-1234ze and the lower process temperature requires longer extraction times.

\section{Conclusion}

The applicability of HFO-1234ze as a new solvent for extraction of natural products was evaluated. A relative solvent screening using HSP and COSMO-RS simulation tools showed that HFO$1234 z e$ can be an alternative only for the extraction of lipophilic compounds. The experimental laboratory study confirms these theoretical simulations. In the case of hydrophilic solutes, only little amount of the target compounds was detected in the final extracts, in accordance with in-silico simulations. For lipophilic compounds, qualitative comparison of the extracts showed similar profiles between HFO-1234ze and $n$-hexane, with even higher purity for carrots oleoresin when using liquefied gas. However, the extraction yields obtained using HFO-1234ze were always significantly lower than the reference, due to the lower solubility of the lipophilic compounds compared to $n$-hexane.

Finally, the evaluation of the industrial feasibility regarding to technology, quality, safety, economic and environmental impact, tends to prove that HFO-1234ze could be a safe potential industrial alternative to several usual solvents for the extraction of natural compounds.

Currently, the regulatory context still restrains the use of HFO1234ze only for non-food applications. However, HFO-1234ze offers a greener alternative to R134a which is already accepted as extraction solvent in Europe (European Parliament, 2009), therefore there is no technical reason to prevent HFO-1234ze of being used for foodstuff production in the future.

\section{Acknowledgements}

The authors are grateful to the French organization ANRT ("Association Nationale de la Recherche et de la Technologie ») for funding this work.

\section{References}

Achaichai, N. (2010). HFOs come on the scene in refrigeration and air conditioning systems [Climalife website]. Retrieved from http://climalife.dehon.com/hfoscome-on-the-scene-in-refrigeration-and-air-conditioning-systems/technical_ file/show/id/5.

Ahangari, B., \& Sargolzaei, J. (2012). Extraction of pomegranate seed oil using subcritical propane and supercritical carbon dioxide. Theoretical Foundations of Chemical Engineering, 46(3), 258-265.

Breil, C., Meullemiestre, A., Vian, M., \& Chemat, F. (2016). Bio-based solvents for green extraction of lipids from oleaginous yeast biomass for sustainable aviation biofuel. Molecules, 21(2), 196.

Capeletto, C., Conterato, G., Scapinello, J., Rodrigues, F. S., Copini, M. S., Kuhn, F., et al. (2016). Chemical composition, antioxidant and antimicrobial activity of guavirova (Campomanesia xanthocarpa Berg) seed extracts obtained by supercritical CO2 and compressed n-butane. The Journal of Supercritical Fluids, 110(1), $32-38$.

Castaneda-Acosta, J., Cain, A. W., Fischer, N. H., \& Knopf, F. C. (1995). Extraction of bioactive sesquiterpene lactones from Magnolia grandiflora using supercritical carbon dioxide and near-critical propane. Journal of Agricultural and Food Chemistry, 43(1), 63-68.

Cerny, C. (2000). Analysis of rosemary volatiles using 1,1,1,2-tetrafluoroethane as extraction solvent. Garching: Deutsche Forschungsanstalt fuer Lebensmittelchemie.

Chemat, F., Rombaut, N., Fabiano-Tixier, A.-S., Pierson, J. T., \& Bily, A. (2015). Green extraction: From concepts to research, education, and economical opportunities. In F. Chemat, \& J. Strube (Eds.), Green extraction of natural products (pp. 1-36). Weinheim, Germany: Wiley-VCH Verlag GmbH \& Co. KGaA.

Corso, M. P., Fagundes-Klen, M. R., Silva, E. A., Cardozo, L., Santos, J. N., Freitas, L. S., et al. (2010). Extraction of sesame seed (Sesamun indicum L.) oil using compressed propane and supercritical carbon dioxide. Journal of Supercritical Fluids, 52(1), 56-61.

European Food Safety Authority. (2008). Scientific opinion of the panel on food 
additives, flavourings, processing aids and materials in contact with food. The EFSA Journal, 721(1), 1-29.

European Parliament. (2009). Directive 2009/32/EC of the European Parliament and of the Council of 23 April 2009 on the approximation of the laws of the Member States on extraction solvents used in the production of foodstuffs and food ingredients. Official Journal of the European Union, L141(3), 3-11.

Grand View Research. (2016). Hexane market analysis by grade (polymerization, extraction), by application (edible oil extraction, industrial solvent, adhesive formulation, leather treatment) and segment forecasts to 2024 (Market Research Report No. GVR-1-68038-122-1). San Fransisco: Grand View Research Inc.

Han, Y., Ma, Q., Wang, L., \& Xue, C. (2012). Extraction of astaxanthin from Euphausia pacific using subcritical 1,1,1,2-tetrafluoroethane. Journal of Ocean University of China, 11(4), 562-568.

Hasan, N., \& Farouk, B. (2013). Mass transfer enhancement in supercritical fluid extraction by acoustic waves. The Journal of Supercritical Fluids, 80(1), 60-70.

Henderson, R. K. Jiménez-González, C. Constable, D. J. C. Alston, S. R. Inglis, G. G. A., Fisher, G., et al. (2011). Expanding GSK's solvent selection guide - embedding sustainability into solvent selection starting at medicinal chemistry. Green Chemistry, 13(4), 854-862.

Jacotet-Navarro, M., Rombaut, N., Fabiano-Tixier, A.-S., Danguien, M., Bily, A., \& Chemat, F. (2015). Ultrasound versus microwave as green processes for extraction of rosmarinic, carnosic and ursolic acids from rosemary. Ultrasonics Sonochemistry, 27(1), 102-109.

Kanda, H., Kamo, Y., Machmudah, S., Wahyudiono, E. Y., \& Goto, M. (2014). Extraction of fucoxanthin from raw macroalgae excluding drying and cell wall disruption by liquefied dimethyl ether. Mar Drugs, 12(5), 2383-2396.

Kanda, Hideki, Li, P., Ikehara, T. \& Yasumoto-Hirose, M. (2015). Lipids extracted from several species of natural blue-green microalgae by dimethyl ether: Extraction yield and properties. Fuel, 95(1), 88-92.

Knockaert, G., Pulissery, S. K., Lemmens, L., Van Buggenhout, S., Hendrickx, M., \& Van Loey, A. (2013). Isomerisation of carrot $\beta$-carotene in presence of oil during thermal and combined thermal/high pressure processing. Food Chemistry, 138(2-3), 1515-1520.

Lapkin, A. A., Plucinski, P. K., \& Cutler, M. (2006). Comparative assessment of technologies for extraction of artemisinin. Journal of Natural Products, 69(11), 1653-1664.

Liu, H. M., Wang, F. Y., Li, H. Y., Wang, X. D., \& Qin, G. Y. (2015). Subcritical butane and propane extraction of oil from rice bran. Bioresources, 10(3), 4652-4662.
Luecken, D. J., L.Waterland, R., Papasavva, S., Taddonio, K. N., Hutzell, W. T., Rugh, J. P., et al. (2010). Ozone and TFA Impacts in North America from degradation of 2,3,3,3-tetrafluoropropene (HFO-1234yf), a potential greenhouse gas replacement. Environmental Science \& Technology, 44(1), 343-348.

Novello, Z., Scapinello, J., Magro, J. D., Zin, G., Luccio, M. D., Tres, M. V., et al. (2015). Extraction, chemical characterization and antioxidant activity of andiroba seeds oil obtained from pressurized n-butane. Industrial Crops and Products, 76(1), 697-701.

Rapinel, V., Rombaut, N., Rakotomanomana, N., Vallageas, A., Cravotto, G., \& Chemat, F. (2016). An original approach for lipophilic natural products extraction: Use of liquefied n-butane as alternative solvent to n-hexane. LWT - Food Science and Technology. http://dx.doi.org/10.1016/j.lwt.2016.10.003 (in press).

Sakuragi, K., Li, P., Aoki, N., Otaka, M., \& Makino, H. (2016). Oil recovery from wet Euglena gracilis by shaking with liquefied dimethyl ether. Fuel Processing Technology, 148(1), 184-187.

Sicaire, A.-G. (2016). Solvants alternatifs et techniques innovantes pour l'éco-extraction des huiles végétales à partir de graines oléagineuses (Doctoral thesis). Avignon: Université d'Avignon et des Pays du Vaucluse.

Sicaire, A.-G., Vian, M., Fine, F., Carre, P., Tostain, S., \& Chemat, F. (2015). Experimental approach versus COSMO-RS assisted solvent screening for predicting the solubility of rapeseed oil. OCL, 22(4), 1-7.

Sicaire, A.-G., Vian, M., Fine, F., Joffre, F., Carre, P., Tostain, S., et al. (2015). Alternative bio-based solvents for extraction of fat and oils: Solubility prediction, global yield, extraction kinetics, chemical composition and cost of manufacturing. International Journal of Molecular Sciences, 16(4), 8430-8453.

Suberu, J., Yamin, P., Cornell, R., Sam, A., \& Lapkin, A. (2016). Feasibility of using 2,3,3,3-tetrafluoropropene (R1234yf) as a solvent for solid-liquid extraction of biopharmaceuticals. ACS Sustainable Chemistry \& Engineering, 4(5), 2559-2568.

Wallington, T. J., Sulbaek Andersen, M. P., \& Nielsen, O. J. (2010). Estimated photochemical ozone creation potentials (POCPs) of CF3CFCH2 (HFO-1234yf) and related hydrofluoroolefins (HFOs). Atmospheric Environment, 44(11) 1478-1481.

Yara-Varon, E., Fabiano-Tixier, A. S., Balcells, M., Canela-Garayoa, R., Bily, A., \& Chemat, F. (2016). Is it possible to substitute hexane with green solvents for extraction of carotenoids? A theoretical versus experimental solubility study. RSC Advances, 6(33), 27750-27759.

Yateem, H., Afaneh, I., \& Al-Rimawi, F. (2014). Optimum conditions for oleuropein extraction from olive leaves. International Journal of Applied, 4(5), 153-157. 